\title{
Kontrol Methanogenesis Pada Ruminansia Dan Kontribusinya Terhadap Pencegahan Polusi Lingkungan
}

\author{
B. Santoso dan Th. Sraun \\ Jurusan Nutrisi dan Makanan Temak, Fakultas Peternakan Perikanan \\ dan Ilmu Kelautan, Universitus Negeri Papua
}

\begin{abstract}
Methane ( $\left.\mathrm{CH}_{4}\right)$ is produced as a result of anaerobic fermentation of the soluble and structural carbohydrates by methanogens in the rumen of ruminant animals, which is released into the environment by eructation. Methane production from ruminant range from 2 to $12 \%$ of the gross energy intake and represents a substantial loss in efficiency of animal production. Recently. $\mathrm{CH}_{4}$ production by ruminants has also received attention due to its contribution to global warming. Much research has been carried out on the manipulation of rumen fermentation to inhibit methanogenesis. Several strategies can be treated to reduce $\mathrm{CH}_{s}$ production in the rumen such as by feed manipulation (composition, feeding level) or by the use of both chemical and natural feed additives. More biotechnological inrferventions e.g., defanmation, probiotics and prebiotics, and introduction of reductive acetogenesis in the rumen, are also mentioned. Chemical inhibitors have proved to be effective in decreasing $\mathrm{CH}_{4}$ e production to variying degrees. Problems with chemical inhibitors have been noted, such as rumen microbial adaptation, toxicity to the host, residues in endible products and an inability to increase energetic afficiency.
\end{abstract}

Key words: methan; ruminant; environment; feed additive.

\section{Pendahuluan}

Gas methan $\left(\mathrm{CH}_{4}\right)$ merupakan hasil fermentasi anaerob karbohidrat struktural maupun non-struktural oleh methanogen (bakteri penghasil methan) di dalam rumen ternak ruminansia, selanjutnya dikeluarkan ke atmosfer melalui proses eruktasi. Sapi dewasa menghasilkan $\mathrm{CH}_{4}$ bervariasi dari $2-12 \%$ dari konsumsi energi kasar (gross energy intake) atau setara dengan $250-500 /$ ekor/hari (Johnson and Johnson, 1995). Sementara itu dari 1137 data, Pelchen and Peters (1998) menyimpulkan bahwa rata-rata produksi $\mathrm{CH}_{4}(\%$ konsumsi energi kasar) pada ternak domba adalah 7,22\% atau setara dengan 31/ekor/hari. Menurut Brouwer (1965), nilai konversi energi dari gas $\mathrm{CH}_{4}$ adalah $39,54 \mathrm{~kJ} / \mathrm{l}$. Hal tersebut menunjukkan bahwa produksi serta pengeluaran gas $\mathrm{CH}_{4}$ dari ternak ruminansia mengindikasikan energi yang hilang dari tubuh ternak. Disamping itu, gas $\mathrm{CH}_{4}$ yang dihasilkan oleh ternak ruminansia telah mendapat perhatian yang serius dalam beberapa tahun terakhir ini karena berkontribusi terhadap pemanasan global di atmosfer. Menurut Moss (1994), $\mathrm{CH}_{4}$ mempunyai efektifitas radiasi yang lebih besar dibandingkan $\mathrm{CO}_{2}$ (21 vs. 1 /molekul), serta waktu paruh di atmosfer lebih pendek daripada $\mathrm{CO}_{2}(10$ vs. 200 tahun).

Populasi ruminansia di dunia menghasilkan 77 juta ton $\mathrm{CH}_{4} /$ tahun atau sebesar $12-15 \%$ dari total 
pencemaran $\mathrm{CH}_{4}$ di atmosfer. Sementara itu, $\mathrm{CH}_{4}$ menempati urutan kedua $(18 \%)$ setelah $\mathrm{CO}_{2}$ dalam kontribusi terhadap pemanasan global dibandingkan dengan gas lainnya (Moss, 1993), sebagaimana tertera pada Gambar 1.

\section{Methanogenesis Dalam Rumen}

Methanogen adalah suatu grup bakteri yang mempunyai sifat halopilik dan thermoasidophilik (Moss, 1993), dikelompokkan dalam klas Archae dengan kingdom Euryaarcaeota (Balch and Wolfe, 1979). Bakteri methanogen hidup dalam kondisi potensial redoks kurang dari $-300 \mathrm{mV}$ (Stewart and Bryant, 1988) dan sebagian besar hidup dalam keadaan $\mathrm{pH}$ netral dengan kisaran $\mathrm{pH}$ optimum $6-8$ (Jones et al, 1987). Bakteri ini dikelompokkan dalam Gram positif dengan ukuran lebar dan panjang berturut-turut sekitar 1,8 $\mu \mathrm{m}$ dan 1,52,0 $\mu \mathrm{m}$ (Takahashi, 2001). Enam spesies methanogen telah diisolasi dari dalam rumen dan hanya dua spesies yaitu Methanobrevibacter ruminantium dan Methanosarcina sp. yang terdapat dalam populasi yang besar lebih dari $1 \times 10^{6} / \mathrm{ml}$ (McAllister et al., 1996).

Selama fermentasi karbohidrat dalam rumen, sebagian mikroorganisme rumen menggunakan jalur Embden-Meyerhoff-Parnas and pentose phosphate dalam memfermentasi polisakarida (heksosa dan pentosa) menjadi piruvat. Selanjutnya piruvat dimetabolisir melalui berbagai jalur dengan hasil akhir seperti format, asetat, propionat, butirat, laktat, suksinat methanol, ethanol, $\mathrm{CO}_{2}$ dan $\mathrm{H}_{2}$ (Tabel 1).
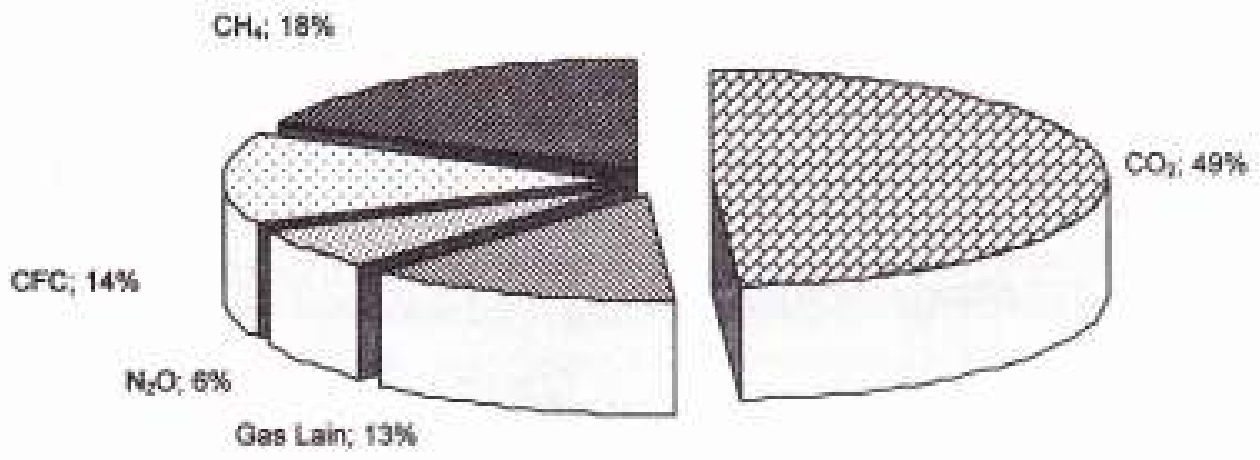

Gambar 1. Kontribusi Berbagai Gas Terhadap Pemanasan Global (Sumber: Moss et al., 1993) 
Tabel 1. Spesies dan Karakteristik Methanogen yang Diisolasi Dari Rumen

\begin{tabular}{|c|c|c|}
\hline Organisme & $\begin{array}{c}\text { Morfologi, Komposisi } \\
\text { Sel Penutup }\end{array}$ & Sumber Energi \\
\hline $\begin{array}{l}\text { Methanobrevibacter } \\
\text { ruminantium }\end{array}$ & $\begin{array}{l}\text { Batang pendek, } \\
\text { membutuhkan KoM, PS }\end{array}$ & $\mathrm{H}_{2} /$ format \\
\hline Methanobrevibacter sp. & $\begin{array}{l}\text { Batang pendek, sintesis } \\
\text { KoM, PS }\end{array}$ & $\mathrm{H}_{2} /$ format \\
\hline Methanosarcina barkeri & $\begin{array}{l}\text { Kokkus tidak beraturan } \\
\text { Kelompok panjang, } \\
\text { HPS+PR }\end{array}$ & $\begin{array}{l}\mathrm{H}_{2} / \text { metanol } \\
\text { methylamin/asetat }\end{array}$ \\
\hline Methanosarcina mazei & Kokkus, HPS & $\begin{array}{l}\mathrm{H}_{2} / \text { metanol } \\
\text { methylamin/asetat }\end{array}$ \\
\hline Methanobacterium formicicum & $\begin{array}{l}\text { Batang panjang dan } \\
\text { berfilamen, PS }\end{array}$ & $\mathrm{H}_{2} /$ format \\
\hline Methanomicrobium mobile & Batang pendek, PR & $\mathrm{H}_{2} /$ format \\
\hline
\end{tabular}

KoM, koenzim M; PS, pseudomerin; HPS, heteropolisakarida; PR, protein.

Sumber: McAllister et al. (1996).

Methanogen seperti Methanobrecibacter ruminantium dan Methanosarcina barkeri menggunakan $\mathrm{H}_{2}$ dan $\mathrm{CO}_{2}$ atau format, asetat, methiamin, dan methanol menjadi $\mathrm{CH}_{4}$, selanjutnya dikeluarkan ke atmosfer melalui proses eruktasi. Penggunaan $\mathrm{H}_{2}$ oleh methanogen berperan penting dalam mempertahankan fermentasi yang normal dalam rumen (Mathison et al., 1998) dan homeostasis ekosistem rumen (Takahashi, 2001). Secara sederhana pola fermentasi karbohidrat dalam rumen adalah 57,5 glukosa $\rightarrow 65$ asetat +20 propionat +15 butirat + $35 \mathrm{CH}_{4}+60 \mathrm{CO}_{2}+25 \mathrm{H}_{2} \mathrm{O}$ (Wolin, 1979). DiMarco et al. (1990) menyatakan dalam reaksi reduksi $\mathrm{CO}_{2}$ menjadi $\mathrm{CH}_{4}$ melibatkan enam koenzim melalui tujuh tahap reaksi. Menurut Mathison et al. (1998), koenzim M (2 - asam mercaptoethanesulfonat atau (CM) juga dibutuhkan sebagai kofaktor pada reaksi terakhir dari methanogenesis. Gas $\mathrm{H}_{2}$ dan $\mathrm{CO}_{2}$ banyak dihasilkan oleh bakteri ketika ternak mengkonsumsi pakan yang berserat. Substrat yang utama dari pembentukan gas $\mathrm{CH}_{4}$ adalah karbohidrat struktural yang dapat tercerna seperti hemisellulosa (Gambar 2). Dengan demikian hijauan dengan serat kasar yang tinggi dan dapat dicerna akan menghasilkan gas $\mathrm{CH}_{4}$ yang tinggi.

Pada proses methanogenesis terjadi transfer $\mathrm{H}_{2}$ antara bakteri selulolitik (McAllister et al., 1998); bakteri non-selulolitik (Chen and Wolin, 1977); jamur (Joblin et al., 1989) dan protozoa (Stum et al., 1982) dengan methanogen. Transfer $\mathrm{H}_{2}$ antara mikroorganisme rumen dengan methanogen, tertera pada Tabel 1 . Sejumlah methanogen ditemukan pada permukaan protozoa entodiniomorp (Tokura et al., 1997) yang berfungsi dalam mengontrol konsentrasi hydrogen pada cairan rumen, karena lebih dari $50 \%$ digesti pati dilakukan oleh protozoa dan kecernaan fraksi dinding sel (ADF) meningkat sekitar $15 \%$ dengan adanya protozoa 
(faunasi) (Jouany and Ushida, 1999). bahwa sekitar $9-25 \%$ methanogen Sementara itu, Stumm et al. (1982); bersimbiosis dengan protozoa.

Newbold et al. (1995) menyimpulkan

Tabel 2. Transfer $\mathrm{H}_{2}$ antara Mikroorganisme Rumen dengan Methanogen

\begin{tabular}{|c|c|c|c|c|}
\hline & Substrat & $\begin{array}{l}\text { Waktu } \\
\text { Inkubasi } \\
\text { (hari) }\end{array}$ & $\begin{array}{c}\text { Peningkatan } \\
\text { Kecernaan } \\
(\%)\end{array}$ & $\begin{array}{c}\text { Perubahan } \\
\text { Produk } \\
\text { Fermentasi }\end{array}$ \\
\hline \multicolumn{5}{|l|}{ Bakteri selulolitik } \\
\hline $\begin{array}{l}\text { Ruminococcus flavefaciens } \\
\text { dengan } \\
\text { Methanobrevibacter } \\
\text { ruminantium }\end{array}$ & Selulosa & 7 & TH & $\begin{array}{l}\mathrm{A}, \mathrm{S} \downarrow \\
\mathrm{F} \downarrow, \mathrm{H}_{2} \downarrow \\
\mathrm{CH}_{4} \uparrow\end{array}$ \\
\hline $\begin{array}{l}\text { Ruminococcus albus dengan } \\
\text { Methanobrevibacter smithii }\end{array}$ & $\begin{array}{l}\text { Jerami } \\
\text { barley }\end{array}$ & 10 & 4,6 & $\begin{array}{l}\mathrm{E} \leftrightarrow, \mathrm{H}_{2 \downarrow} \\
\mathrm{CH}_{4} \uparrow\end{array}$ \\
\hline \multicolumn{5}{|l|}{ Bakteri non-selulolitik } \\
\hline $\begin{array}{l}\text { Selemonas ruminantium } \\
\text { dengan } \\
\text { Methanobrevibacter } \\
\text { ruminantium }\end{array}$ & Glukosa & 3 & TH & $\begin{array}{l}\mathrm{A}, \mathrm{L} \downarrow \\
\mathrm{F} \downarrow, \mathrm{P} \downarrow \\
\mathrm{CH}_{4} \uparrow\end{array}$ \\
\hline \multicolumn{5}{|l|}{ Jamur anserobik } \\
\hline $\begin{array}{l}\text { Neocallimastix frontalis } \\
\text { dengan }\end{array}$ & Jerami & 10 & 12,8 & $\begin{array}{l}\mathrm{E} \downarrow, \mathrm{L} \downarrow \\
\mathrm{H} \downarrow\end{array}$ \\
\hline Methanobrevibacter smïhï & barley & & & $\mathrm{CH}_{4} \uparrow$ \\
\hline Piromyces communis dengan & Jerami & 10 & 5,8 & $\begin{array}{l}\mathrm{E} \downarrow, \mathrm{L} \downarrow \\
\mathrm{H}_{2} \downarrow\end{array}$ \\
\hline Methanobrevibacter smithii & barley & & & $\mathrm{CH}_{4} \uparrow$ \\
\hline $\begin{array}{l}\text { Neocallimastìx patriciarum } \\
\text { dengan } \\
\text { Methanobrevibacter smithii }\end{array}$ & Selulosa & 14 & 9 & $\begin{array}{l}\mathrm{A} \uparrow, \mathrm{E} \downarrow \\
\mathrm{E} \downarrow, \mathrm{L} \downarrow \\
\mathrm{S} \downarrow, \mathrm{H}_{2} \downarrow \\
\mathrm{CH}_{4} \uparrow\end{array}$ \\
\hline \multicolumn{5}{|l|}{ Protozoa } \\
\hline $\begin{array}{l}\text { Isotricha spp. dengan } \\
\text { Methanosarcina barkeri }\end{array}$ & Glukosa & 4 & - & $\begin{array}{l}\mathrm{A} \uparrow, \mathrm{B} \downarrow \\
\mathrm{P} \downarrow, \mathrm{L} \downarrow \\
\mathrm{CH}_{4} \uparrow\end{array}$ \\
\hline
\end{tabular}

TH: tidak dihitung; Asasetat; B:butirat; E:ethanol; F:format; L:laktat; P:propionat; $\uparrow$ :meningkat; I:menurun; $\leftrightarrow$ :jumlah produk tidak berubah dengan adanya methanogen

Sumber : McAllister et al. (1996). 

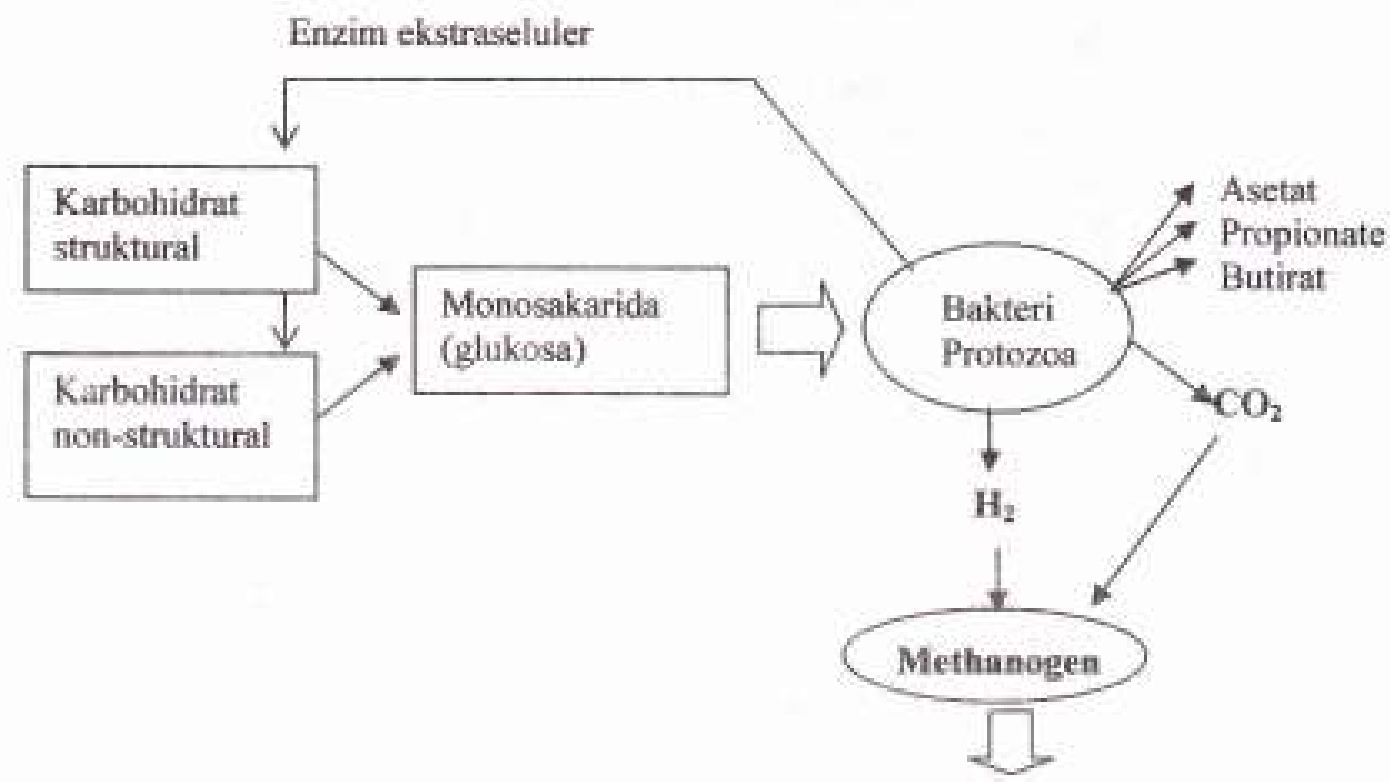

$\mathrm{CH}_{4}$
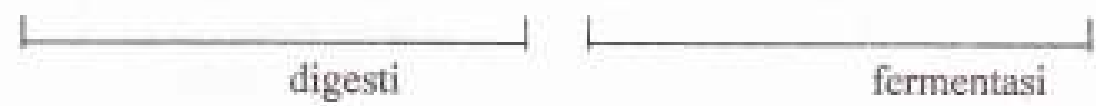

Gambar 2. Digesti dan Fermentasi Karbohidrat di Dalam Rumen Oleh Bakteri dan Protozoa, serta Hubungannya dengan Methanogenesis

Tabel 3. Produksi Gas $\mathrm{CH}_{4}$ pada Heifer, Domba dan Kambing yang Diberi Pakan Hay Rumput Orchard pada Level $150 \%$ TDN

\begin{tabular}{lrrc}
\hline & \multicolumn{3}{c}{ Ternak } \\
\cline { 2 - 4 } & Heifer & Domba & Kambing \\
\hline $\mathrm{CH}_{4}$ (l/hari) & 230,9 & 34,3 & 25,2 \\
$\mathrm{CH}_{4}\left(1 / \mathrm{kg} \mathrm{BB}^{0,75}\right)$ & 2,6 & 1,4 & 1,7 \\
$\mathrm{CH}_{4}(\mathrm{l} / \mathrm{kg}$ konsumsi BK) & 28,4 & 25,9 & 27,1 \\
\hline Sumber: Shibata et al. (1992b) & & &
\end{tabular}

\section{Produksi Gas Methan Ternak Ruminansia}

Gas $\mathrm{CH}_{4}$ yang dihasilkan ternak ruminansia tergantung dari spesies ternak dan dipengaruhi oleh jenis pakan yang dikonsumsi. Sapi (heifer) dapat menghasilkan gas $\mathrm{CH}_{4}$ sekitar 7 kali dan 9 kali lebih tinggi dibandingkan domba dan kambing (Shibata et al., 1992b). Perbandingan produksi $\mathrm{CH}_{4}$ dari ketiga spesies tersebut yang diberi pakan basal hay, tertera pada Tabel 3.

Pada percobaan lain, Shibata et al. (1992a) melaporkan bahwa produksi $\mathrm{CH}_{4}$ dipengaruhi oleh jenis pakan yang dikonsumsi ternak. Rata- 
rata produksi $\mathrm{CH}_{4}$ dari 3 jenis ternak (sapi, domba dan kambing) yang diberi pakan hay dan konsentrat dengan rasio 30:70 (H30) lebih rendah dibandingkan dengan 70:30 (H70). Rendahnya $\mathrm{CH}_{4}$ pada kelompok $\mathrm{H} 30$ disebabkan kandungan selulosa dan kecernaan fraksi serat yang rendah. Disamping itu proporsi konsentrat yang tinggi dalam suatu pakan akan memacu pertumbuhan sel mikroba dan produksi asam propionat. Santoso et al. (unpublished data) menyimpulkan bahwa produksi $\mathrm{CH}_{4}$ dipengaruhi oleh jumlah NDF tercerna. Hal ini terlihat dari produksi $\mathrm{CH}_{4}$ pada domba yang diberi pakan basal silase rumput timothy (S) lebih tinggi dibandingkan hay rumput timothy $(\mathrm{H})$ dengan jumlah NDF tercerna masing-masing 0,4 dan $0,32 \mathrm{~kg} /$ hari (Gambar 3).

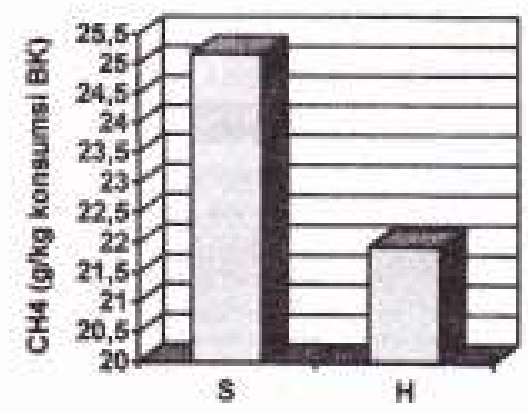

Gambar 3. Produksi $\mathrm{CH}_{4}$ pada domba yang diberi pakan basal silase $(\mathrm{S})$ dan hay $(\mathrm{H})$.

Sementara itu, Kurihara et al. (1999) melaporkan bahwa sapi Brahman yang diberi pakan dengan proporsi konsentrat yang tinggi $(\mathrm{K})$ menghasilkan $\mathrm{CH}_{4}$ lebih rendah dibandingkan yang diberikan rumput Angelton (A) atau rumput Rodhes (R) (Gambar 4), hal ini diduga berhubungan dengan komposisi hemiselulosa dan selulosa dari masingmasing pakan tersebut.

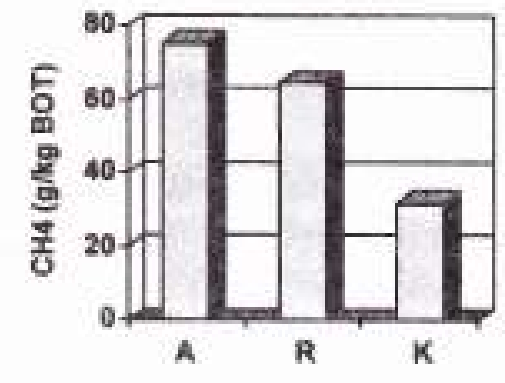

Gambar 4. Produksi $\mathrm{CH}_{4}$ pada sapi Brahman yang diberi pakan rumput Ageiton (A), rumput Rhodes $(R)$ dan alfalfa+ konsentrat $(K)$.

Menurut Moe and Tyrrell (1979), terdapat perbedaan dari masing-masing komponen karbohidrat terhadap produksi $\mathrm{CH}_{4}$ pada sapi. Produksi $\mathrm{CH}_{4}$ setiap gram selulosa yang tercerna sekitar 3 kali lebih tinggi dibandingkan setiap gram hemiselulosa dan sekitar 5 kali lebih tinggi dibandingkan setiap gram karbohidrat yang mudah larut. Shibata et al. (1992b) menyimpulkan bahwa produksi $\mathrm{CH}_{4}$ pada ruminansia yang diberi pakan kurang dari 1,5 kebutuhan hidup pokok dapat diprediksi melalui konsumsi pakan, namun demikian koefisien determinasi $\left(r^{2}\right)$ akan meningkat dengan menggunakan variabel serat kasar, ADF, pati dan ekstrak tanpa nitrogen, sebagaimana tertera pada Tabel 4 .

\section{Strategi Untuk Menurunkan Produksi Methan}

\section{Manipulasi Pakan tanpa Suplementasi Pakan Aditif (feed additive)}

Menurut Blaxter and Clapperton (1965), produksi $\mathrm{CH}_{4}(\mathrm{~kJ}$ per $100 \mathrm{~kJ}$ dalam pakan) menurun sejalan dengan 
peningkatan level pemberian pakan. Disamping itu pemberian karbohidrat struktural (selulosa dan hemiselulosa) yang terfermentasi lebih lambat di dalam rumen dibandingkan karbohidrat non-struktural (pati dan gula) menghasilkan $\mathrm{CH}_{4}$ lebih banyak per unit substrat yang terfermentasi.

Pemberian konsentrat/biji-bijian dengan proporsi yang lebih banyak menurunkan $\mathrm{pH}$ dalam rumen sehingga menghambat methanogen dan protozoa. Disamping itu, pemberian biji-bijian menyebabkan penurunan methanogenesis yang diikuti dengan peningkatan proporsi asam propionat, karena terjadi kompetisi penggunaan $\mathrm{H}_{2}$ pada reaksi pembentukan propionat dan methanogenesis (Van Nevel and Demeyer, 1996). Berdasarkan hubungan tersebut maka dapat dilakukan beberapa menipulasi pakan untuk menurunkan perbandingan asam asetat dan propionat $(\mathrm{A}: \mathrm{P})$, misalnya :

- Meningkatkan proporsi karbohidrat mudah terfermentasi dan menurunkan jumlah pakan kasar.

- Melakukan perlakuan fisik seperti grinding dan pelleting terhadap pakan hijauan, serta pemanasan terhadap biji-bijian.

- Menurunkan frekuensi pemberian pakan sehingga meningkatkan proporsi propionat

\section{Manipulasi dengan Pakan Aditif (feed additive)}

a. Suplementasi asam lemak tidak jemuh

Methanogen membutukkan $\mathrm{H}_{2}$ untuk membentuk $\mathrm{CH}_{4}$ dan beberapa mikroorganisme dalam rumen menggunakan $\mathrm{H}_{2}$ untuk menghidrogenasi ikatan rangkap dari asam lemak tidak jenuh. Akibat adanya kompetisi antara methanogen dan mikroorganisme lain terhadap ketersediaan $\mathrm{H}_{2}$ maka penambahan asam lemak tidak jenuh dalam pakan dapat menghambat produksi $\mathrm{CH}_{4}$. Pengaruh penambahan asam lemak tidak jenuh terhadap produksi $\mathrm{CH}_{4}$ disajikan pada Tabel 5.

Data pada Tabel 5 menunjukkan bahwa konsentrasi $\mathrm{CH}_{4}$ lebih rendah pada kelompok kambing yang diberi asam lemak tidak jenuh dibandingkan kontrol. Pengaruh asam lemak tidak jenuh lebih signifikan sejalan dengan meningkatnya ikatan rangkap dari asam lemak tersebut.

Tabel 4. Analisis Regresi Produksi $\mathrm{CH}_{4}$ Terhadap Kandungan Nutrien dan Nutrien Tercerna (g/hari).

\begin{tabular}{lcr}
\hline \multicolumn{1}{c}{ Persamaan Regresi } & $\mathrm{r}^{2}$ atau $\mathrm{R}^{2}$ & \multicolumn{1}{c}{$\mathrm{SE}$} \\
\hline $\mathrm{CH}_{4}=0,0305 \mathrm{BK}-4,441$ & 98,4 & 13,6 \\
$\mathrm{CH}_{4}=0,0356 \mathrm{SK}+0,045 \mathrm{ETN}-4,714$ & 98,9 & 11,2 \\
$\mathrm{CH}_{4}=0,0470 \mathrm{BKT}-5,364$ & 99,1 & 10,1 \\
$\mathrm{CH}_{4}=0,0774 \mathrm{SKT}+0,0552 \mathrm{ETNT}-3,836$ & 99,2 & 9,7 \\
$\mathrm{CH}_{4}=0,135$ ADFT $+0,0620 \mathrm{PT}-4,141$ & 98,9 & 11,2 \\
\hline
\end{tabular}

BKT : bahan kering tercema; SKT : serat kasar tercema; ETNT: ekstrak tanpa nitrogen tercerna; ADFT: acid detergent fiber tercerna; PT : pati tercerna; $r^{2}$ atau $R^{2}$; koefisien determinasi; SE : standard error.

Sumber: Shibata et al. (1992b) 
Tabel 5. Pengaruh Penambahan Asam Lemak Tidak Jenuh Terhadap Produksi $\mathrm{CH}_{4}$ pada Kambing yang Diberi Pakan Basal Hay dan Konsentrat $(60: 40)$

\begin{tabular}{lccc}
\hline & \multicolumn{3}{c}{ Perlakuan } \\
\cline { 2 - 4 } & Kontrol & C18:0* & C18:1* \\
\hline Konsumsi BK (g/hari) & 714 & 745 & 744 \\
Koefisien Cerna BK (\%) & 64,2 & 64,7 & 65,3 \\
$\mathrm{CH}_{4}(\mathrm{l} / \mathrm{kg}$ konsumsi BK) & 32,4 & 31,2 & 28,8 \\
\hline $\mathrm{C18}: 0$ (asam stearat); C18:1 (asam oleat): * suplementasi 31 8 BK
\end{tabular}

C18 : 0 (asam stearat); C18: 1 (asam oleat); "suplementasi $31 \mathrm{~g}$ BK

Sumber: Kurihara et al. (1997)

\section{b. Suplementasi senyawa kimia}

Dari hasil penelitian menunjukkan bahwa beberapa senyawa kimia dapat digunakan untuk mengeliminasi protozoa dalam rumen seperti dioctylsodium sulfosuccinate (Rowe et al., 1985) dan detergen (Burggraaf and Leng, 1980), Penurunan populasi protozoa dalam rumen akan mengurangi produksi gas $\mathrm{CH}_{4}$, karena sekitar $37 \%$ dari total produksi $\mathrm{CH}_{4}$ dihasilkan dari endosimbiotik antara methanogen dan protozoa.

Sementara itu beberapa feed additive yang bersifat kimiawi telah dilaporkan mempunyai hubungan secara langsung terhadap methanogen sehingga menurunkan produksi $\mathrm{CH}_{4}$ baik secara in vivo maupun in vitro misalnya monensin (van Nevel and Demeyer, 1977; Wedegaertner and Johnson, 1983); $\propto$-asam bromoethanesulfonat (BES) (Balch and Wolfe, 1979); nitrat/nitrit (Takahashi and Young, 1991). Walaupun demikian, penggunaan senyawa tersebut dalam konsentrasi yang tinggi dan dalam jangka waktu yang lama dapat menimbulkan efek toksik terhadap ternak, sehingga menimbulkan kematian (McAllister et al., 1996).
Monensin merupakan senyawa biologi aktif yang dihasilkan oleh jamur Streptomyces cinamonensis. Monensin diklasifikasikan sebagai ionophor karena berfungsi sebagai fasilitator transport kation monovalen antar membran. Wedegaertner and Johnson (1983) melaporkan bahwa suplementasi $3 \mathrm{~g}$ monensin $/ \mathrm{kg} \mathrm{BB}{ }^{0,75}$ menurunkan produksi $\mathrm{CH}_{4}$ scbanyak $26,6 \%$ dibandingkan kelompok kontrol (14,1 dibandingkan 19,2 $\mathrm{kkal} / \mathrm{kg} \quad \mathrm{BB}^{0,75} /$ hari) (Wedegaertner and Johnson, 1983).

Fumarat merupakan senyawa intermediet pada sintesis propionat melalui jalur suksinat. Beberapa bakteri seperti Fibribacter succinogenes, Selemonas ruminantium spp. ruminantium, Selemonas ruminantium spp. lactilytica, Veillonella parvula dan Wollinella succinogenes mengoksidasi $\mathrm{H}_{2}$ dengan menggunakan fumarat sebagai penerima elektron terakhir, sehingga terjadi kompetisi dengan methanogen dalam penggunaan $\mathrm{H}_{2}$. Namun demikian, affinitas bakteri tersebut terhadap $\mathrm{H}_{2}$ lebih rendah dibandingkan metha-nogen. Asanuma et al. (1999) melaporkan bahwa penambahan fumarat ke dalam pakan ruminansia menurunkan produksi $\mathrm{CH}_{4}$ dan meningkatkan konsentrasi asam propionat. 
Tabel 6. Pengaruh Asam 2-bromoethanolsulfonat (BES) terhadap Persentase Gas Methan dan Hidrogen dalam Rumen Domba

\begin{tabular}{lcc}
\hline & $\mathrm{CH}_{4}(\%)$ & $\mathrm{H}_{2}(\%)$ \\
\hline Periode kontrol $(\mathrm{n}=9)$ & $34,8 \pm 2,9$ & 0 \\
Periode BES & & \\
Hari ke 1 & 0,4 & 31,8 \\
$2 / 3$ & 0,8 & 28,1 \\
4 & 25,5 & 0,2 \\
5 & 18,6 & 0,2 \\
6 & 18,6 & 0,1 \\
7 & 25,1 & 0,1 \\
\hline
\end{tabular}

Hari ke $1,2 \mathrm{~g}$ BES dalam $250 \mathrm{ml}$ air diberikan melalui rumen dan infusi kontinyu; Hari ke 4, infusi dihentikan; Hari ke 5, 6 dan 7, diberikan $0,5 \mathrm{~g}$ BES

Sumber : Van Nevel and Demeyer (1996)

Tabel 7. Pengaruh Saponin $Y$. schidigera dan $S$, saponaria terhadap Methanogenesis

\begin{tabular}{|c|c|c|c|c|c|}
\hline \multirow{2}{*}{$\begin{array}{c}\text { Perco- } \\
\text { baan }\end{array}$} & \multirow[t]{2}{*}{ Konsentrasi } & \multicolumn{2}{|c|}{ Produksi $\mathrm{CH}_{4}$} & \multirow[t]{2}{*}{ Unit } & \multirow[t]{2}{*}{ Pustaka } \\
\hline & & $(-)$ & $(+)$ & & \\
\hline In vitro & $2 \mathrm{ml} / \mathrm{l}^{\mathrm{s}}$ & 430,0 & 250,0 & $\mathrm{ml} / 24 \mathrm{jam}$ & Takahashi et al, 2000 \\
\hline In vitro & $100 \mathrm{mg} / \mathrm{g}^{\mathrm{b}}$ & 6,18 & 4,95 & $\mathrm{mmol} / \mathrm{hari}$ & Hess et al, 2003 \\
\hline In vivo & $30 \mathrm{mg} / \mathrm{kg} \mathrm{BK}^{\circ}$ & 70,9 & 69,1 & $\mathrm{~g} / \mathrm{kg} \mathrm{NDF}$ & Śliwiński et al., 2002 \\
\hline In vivo & 60 ppm dari pakan ${ }^{a}$ & 1,79 & 1,67 & $1 / \mathrm{kg} \mathrm{BB}^{0,75}$ & Santoso et al, 2004 \\
\hline In vivo & 120 ppm dari pakan & 1,88 & 1,71 & $1 / \mathrm{kg} \mathrm{BB}^{0,75}$ & Santoso, 2005 \\
\hline
\end{tabular}

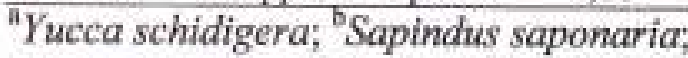

$(-)$ tanpa saponin; $(+)$ penambahan saponin

c. Suplementasi senyawa saponin dan tanin dari tumbuhan

Penggunaan saponin yang berasal dari tumbuhan Yucca schidigera maupun Sapindus saponaria sebagai feed additive dan pengaruhnya terhadap produksi $\mathrm{CH}_{4}$ telah dilaporkan baik secara in vitro maupun in vivo, sebagaimana disajikan pada Tabel 7.

Data pada Tabel 7 menunjukkan bahwa penambahan saponin dengan berbagai konsentrasi menurunkan produksi $\mathrm{CH}_{4}$ baik secara in vitro maupun in vivo. Menurut Hess et al. (2003); Santoso et al. (2004), mekanisme penurunan produksi $\mathrm{CH}_{4}$ sebagai akibat dari penurunan populasi protozoa dalam rumen. Membran protozoa (prokaryotic) lebih sensitif terhadap saponin dibandingkan membran bakteri (eukaryotic) karena adanya sterol pada membrane sel protozoa (Williams and Coleman, 1992), sehingga saponin dapat mengikat sterol yang selanjutnya menyebabkan dekstruksi membran sel protozoa (Hostettmann and Marston, 1995). Selanjutnya penurunan populasi protozoa diikuti dengan penurunan produksi $\mathrm{CH}_{4}$. Sementara itu, penambahan ekstrak Terminalia chebula yang mengandung senyawa tanin efektif menurunkan produksi gas $\mathrm{CH}_{4}$ hingga $95 \%$ dibandingkan 
kelompok kontrol (Patra et al., 2006), sebagaimana tertera pada Tabel 8.

Menurut Sliwiński et al. (2002) bahwa produksi gas $\mathrm{CH}_{4}$ (in vitro) per unit bahan organik terfermentasi cenderung menurun, sejalan dengan peningkatan level ekstrak tanin. Penurunan produksi gas methan sebagai respon dari penambahan ekstrak tanin diduga berhubungan dengan konsentrasi $\mathrm{H}_{2}$. Pada proses methanogenesis, bakteri methanogen menggunakan senyawa $\mathrm{H}_{2}$ dan $\mathrm{CO}_{2}$ atau format, asetat, methiamin, dan methanol menjadi $\mathrm{CH}_{4}$. McSweeney et al. (2001) menyatakan bahwa penurunan produksi gas $\mathrm{CH}_{4}$ dapat pula disebabkan oleh penurunan degradasi karbohidrat struktural akibat terbentuknya suatu kompleks antara tanin dengan selulosa atau hemiselulosa.

\section{d. Suplementasi probiotik dan prebiotik}

Menurut Mwenya et al. (2004) suplementasi $4 \mathrm{~g}$ kultur jamur/hari (probiotik) yang mengandung Trichosporon sericeum 1,2-2,3 $\times 10^{7}$ colony forming unit/g menurunkan produksi $\mathrm{CH}_{4}$ pada domba 10,2\% dibandingkan kontrol. Penurunan ini diduga karena kultur jamur menstimulasi bakteri pembentuk asetat (asetogen) yang juga memanfaatkan $\mathrm{H}_{2}$, sehingga terjadi kompetisi dengan methanogen dalam penggunaan $\mathrm{H}_{2}$. Pada percobaan yang sama, Mwenya et al. (2004) melaporkan bahwa suplementasi prebiotik yaitu $20 \mathrm{~g}$ galakto-oligosakarida menurunkan produksi gas $\mathrm{CH}_{4}$ pada domba $9,8 \%$ dibandingkan kontrol (33,53 dibandingkan 38,17 1/hari). Galaktooligosakarida merupakan senyawa campuran antara galaktosa dan glukosa melalui reaksi enzimatik ( $\beta$-D galaktosidase). Di dalam rumen, galakto-oligosakarida mudah terdegradasi (Santoso et al., 2003) dan menstimulasi pertumbuhan bakteri bifido yang banyak menghasilkan asam propionat (Ogimoto and Imai, 1981 dan Bouhnik et al., 1997). Dengan demikian terjadi kompetisi secara tidak langsung terhadap ketersediaan $\mathrm{H}_{2}$ untuk reaksi sintesis propionat dan methanogenesis.

Pada percobaan in vitro dengan suplementasi probiotik (Saccharomyces cerevisiae dan Aspergilus oryzae), Frumholtz et al. (1989) dan Mutsvanga et al. (1992) melaporkan penurunan $\mathrm{CH}_{4}$ sebagai pengaruh dari suplementasi kedua jenis probiotik tersebut bervariasi $10-$ $50 \%$. Chaucheyras et al, (1995) menyatakan bahwa Saccaromyces cerevisiae mampu menstimulasi bakteri pembentuk asetat (asetogen) dalam menggunakan $\mathrm{H}_{2}$, sehingga terjadi kompetisi antara asetogen dengan methanogen dalam penggunaan $\mathrm{H}_{2}$.

\section{Acetogenesis}

Bakteri asetogen yaitu bakteri yang mampu mengkonversi $\mathrm{CO}_{2}$ dan $\mathrm{H}_{2}$ menjadi asetat. Populasi asetogen bervariasi antar spesies ruminansia, sebagaimana dilaporkan oleh Le Van et al. (1998) dalam Joblin (1999) bahwa popolasi asetogen pada sapi perah yang diberi pakan hay dan konsentrat adalah $2,5 \times 10^{5} / \mathrm{ml}$. Sementara Morvan et al. (1996) dalam Joblin (1999) menyatakan populasi asetogen pada rusa, domba dan bison masing-masing $10^{2}, 10^{2}$, dan $10^{3} / \mathrm{ml}$. Populasi bakteri asetogen tinggi pada domba yang baru lahir (sebelum methanogen beradaptasi) dan pada domba dewasa yang diberi pakan hijauan dalam sedikit. Reduksi $\mathrm{CO}_{2}$ menjadi asetat (asetogenesis) lebih diharapkan daripada reduksi menjadi 
$\mathrm{CH}_{4}$, karena tidak hanya memperkecil energi yang hilang dari dalam tubuh temak, sebaliknya menyediakan asam asetat yang bermanfaat sebagai sumber energi bagi ternak ruminansia. Reaksi pembentukan asetat oleh bakteri sebagai bcrikut :

$4 \mathrm{H}_{2}+2 \mathrm{CO}_{2} \rightarrow \mathrm{CH}_{3} \mathrm{COOH}+2 \mathrm{H}_{2} \mathrm{O}$

Sepuluh asetogen telah diisolasi dari domba muda (pre-ruminan) dan ruminansia dewasa, sebagaimana tertera pada Tabel 9.

Walaupun informasi mengenai asetogen terutama kemampuan memanfaatkan $\mathrm{H}_{2}$ dan ekologinya masih sangat terbatas, namun reaksi pembentukan asetat dapat dipertimbangkan dalam startegi mengontrol methanogenesis pada ternak ruminansia.

Tabel 8. Pengaruh Senyawa Tanin terhadap Methanogenesis

\begin{tabular}{|c|c|c|c|c|c|}
\hline Percobaan & $\begin{array}{c}\text { Konsentrasi } \\
\text { Tanin }\end{array}$ & $\begin{array}{l}\text { Produks } \\
(-)\end{array}$ & $\begin{array}{l}\mathrm{CH}_{4} \\
(+)\end{array}$ & Unit & Pustaka \\
\hline In vitro & $0,25 \mathrm{ml} / 30 \mathrm{ml}^{\mathrm{n}}$ & 31 & 0,3 & $\mathrm{ml} / \mathrm{g} \mathrm{BK}$ & $\begin{array}{l}\text { Patra et al., } \\
2006\end{array}$ \\
\hline In vitro & $160 \mathrm{mg} / 200 \mathrm{mg}^{\mathrm{b}}$ & 20 & 14 & $\% \mathrm{CH}_{4}$ & $\begin{array}{l}\text { Roth et al. } \\
2001\end{array}$ \\
\hline In vivo & $15 \mathrm{~g} / \mathrm{kg}$ PK & 1,55 & 1,30 & $\mathrm{mmol} / \mathrm{g} \mathrm{BOF}$ & $\begin{array}{l}\text { Śliwiński et } \\
\text { al., } 2002\end{array}$ \\
\hline
\end{tabular}

Terminalia chebula, chestnut

BOF : bahan organik terfermentasi; $(-)$; tanpa tanin; $(+)$ : penambahan tanin

Tabel 9. Spesies Asetogen yang Disolasi dari Rumen Domba dan Sapi yang Diberi Berbagai Jenis Pakan.

\begin{tabular}{|c|c|c|c|}
\hline Isolat & Sumber & Pakan ternak & $\begin{array}{c}\mathrm{pH} \\
\text { optimum }\end{array}$ \\
\hline Eubacterium limosum & Rumen domba & Jerami-molases & 7,2 \\
\hline Acetitomaculum ruminis & Rumen sapi & Hay-konsentrat & 6,8 \\
\hline Tidak diketahui & Rumen sapi & Hay-biji-bijian & $6,8-7,5$ \\
\hline Tidak diketahui & Rumen rusa & Rumput-biji-bijian & $7,0-7,5$ \\
\hline $\begin{array}{l}\text { Peptosteptococcus } \\
\text { productus }\end{array}$ & Domba muda & Susu & - \\
\hline Tidak diketahui & Domba muda & Susu & $6,3-6,8$ \\
\hline Ruminococcus shinkii & Domba muda & Susu & $6,5-7,0$ \\
\hline Clostridium difficile & Domba muda & Susu & $6,5-7,0$ \\
\hline Tidak diketahui & Rumen sapi & Rumput segar & $6,5-7,2$ \\
\hline Tidak diketahui & Rumen domba & Rumput segar & $6,5-7,0$ \\
\hline
\end{tabular}




\section{Kesimpulan}

Gas $\mathrm{CH}_{4}$ merupakan hasil fermentasi anaerob karbohidrat struktural maupun non struktural oleh methanogen di dalam rumen ternak ruminansia, yang dikeluarkan ke atmosfer melalui proses eruktasi. Produksi $\mathrm{CH}_{4}$ pada ternak sapi bervariasi 250 - $500 \mathrm{l} /$ hari, sedangkan pada ternak kambing sekitar 31 1/hari. Pengeluaran gas $\mathrm{CH}_{4}$ dari dalam rumen merupakan representasi energi yang hilang dari dalam tubuh dengan rata-rata $6 \%$ dari konsumsi energi kasar, serta mempunyai pengaruh yang signifikan terhadap pencemaran lingkungan. Beberaps strategi/teknik yang dapat dilakukan untuk mereduksi produksi $\mathrm{CH}_{4}$ yang berasal dari ruminansia antara lain melalui manipulasi pakan tanpa atau dengan pakan aditif seperti (asam lemak tidak jenuh, senyawa kimia, senyawa saponin/tanin dari tumbuhan. probiotik dan probiotik) serta meningkatkan kompetisi penggunaan $\mathrm{H}_{2}$ melalui asetogenesis. Walaupun senyawa kimia efektif menurunkan produksi $\mathrm{CH}_{4}$, namun demikian tidak direkomendasikan untuk digunakan dalam sistem produksi ruminansia karena bersifat toksik terhadap ternak serta dapat menimbulkan residu pada produk ternak.

\section{Daftar Pustaka}

Asanuma, N., M. Iwamoto and $T$. Hino. 1999. Effect of the addition of fumarate on methane production by ruminal microorganisms in vitro. J. Dairy Sci. 82: 780-787.

Balch, W. E. and R. S. Wolfe. 1979. Specificity and biological distribution of coenzym M (2mercaptosulphonic acid). J. Bacteriol. 137:260-263.
Blaxter, K.L. and J.L. Clapperton. 1965. Prediction of the amount of methane produced by ruminants. Br. J. Nutr. 19:8190.

Bouhnik, Y., B. Flourie, L. D'AgayAbensour, P. Pochart, G. Gramet, M. Durand and J. Rambaud. 1997. Administration of transgalacto-oligosaccharides increases fecal Bifidobacteria and modifies colonic fermentation metabolism in healthy humans. J. Nutr. 127:444-448.

Brouwer, E. 1965. Report of subcommittee on constants and factors. In: Proceedings of the $3^{\text {rd }}$ EAAP Symposium on Energy Metabolism. K.L. Blaxter (Ed,). Troon, Publ. 11. Academic Press. pp. 441-413.

Burggraaf, W, And R. A. Leng. 1980. Antiprotozoal effects of sufactant detergents in the rumen of sheep. New Zealand J. Agric. Res.23:287-291.

Chaucheyras, F., G. Fonty, G. Bertin and $\mathrm{P}$. Gouet. 1995. In vitro $\mathrm{H}_{2}$ by a ruminal acetogenic bacterium cultived alone or in association with an Archae methanogen is stimulated by a probiotic strain of Saccaromyces cerevisiae. Appl. Environ. Microbiol, 61: 34663467.

Chen, M. and M. J. Wolin. 1977. Influence of methane production by Methanobacterium ruminantium on the fermentation of glucose and lactate by Selemonas ruminantium. Appl. Environ. Microbiol. 34: 756759.

DiMarco, A. A., T. A. Bobik and R. S. Wolfe. 1990. Unusual co- 
enzymes of methanogens. Annu. Rev. Biochem. 59:355-394.

Frumholtz, P. P., C. J. Newbold and R. J. Wallace. 1989. Influence of Aspergilus orizae fermentation extract on the fermentation of a basal ration in the rumen simulation technique (Rusitec). J. Agric. Sci. Camb. 113: 169-172.

Hess, H. D., L. M., Monsalve, C. E., Lascano, J. E., Carulla, T, E. Diaz and M. Kreuzer. 2003. Supplementation of a tropical grass diet with forage legumes and Sapindus saponaria fruits: effects on in vitro ruminal nitrogen turnover and methanogenesis. Aust. J. Agric. Res. 54:703-713.

Hostettmann, K. and A. Marston. 1995. Saponins. Cambridge: Cambridge University Press.

Joblin, K. N. 1999, Ruminal acetogens and their potential to lower ruminant methane emissions. Aust. J. Agric. Res. 50: 1307-1313.

Joblin, K. N., G. P. Champbell, A. J. Richardson and C. S. Stewart. 1989. Fermentation of barley straw by anaerobic rumen bacteria and fungi in axenic culture and in co-culture with methanogens. Lett. Appl. Microbiol. 9: 195-197.

Johnson, K. A. and D. E. Johnson. 1995. Methane emissions from cattle. J. Anim. Sci. 73:24832492.

Jones, W. J., D. P. Jr., Nagle and W. P. Whitman. 1987. Methanogens and the diversity of archaebacteria. Microbiol. Rev. 51:135-177.
Jouany, J. P. and K. Ushida. 1999. The role of protozoa in feed digestion. Asian-Aust. J. Anim. Sci. $12: 113-128$.

Kurihara, M., M. Shibata, T. Nishida, A. Pumomoadi and F. Terada. 1997. Methane production and its dietary manipulation in ruminants. In : $\mathrm{R}$. Onodera, $\mathrm{H}$. Itabashi, K. Ushida, H. Yana and $\mathrm{Y}$. Sasaki. Rumen microbes and Digestive in Ruminants. Japan Sci. Soc. Press. pp. 199 208.

Kurihara, M., T. Magner, R.A. Hunter and G.J. Mc Crabb. 1999. Methane production and energy partition of cattle in the tropics. Br. J. Nutr. 81:227-234.

Mathison, G. W., E. K. Okine, T. A. McAllister, Y. Dong, J. Galbraith and O. I. N. Dmytruk. 1998. Reducing methane emissions from ruminants animals. J. Appl. Anim. Res. $14: 1-28$

McAllister, T. A., E. K. Okine, G. W. Mathison and K-J. Cheng. 1996. Dietary, environmental and microbiology aspects of methane production in ruminants. Can. J. Anim. Sci. 76:231-243.

McSweeney, C. S., B. Palmer, D. M. McNeill and D. O. Krause, 2001. Microbial interactons with tannins: nutritional consequences for ruminants. Anim. Feed Sci. Technol. 91:83-93.

Moe, P. W. and H. F. Tyrrell. 1979. Methane production in dairy cows. J. Dairy Sci. 62:15831586. 
Moss, A. R. 1993. Methane Global Warming and Production by Animals. Chalcombe Publications, Canterbury. p.105.

Moss, A. R. 1994. Methane production by ruminantsLiterature review of I. Dietary manipulation to reduce methane production and II. Laboratory procedures fro estimating methane of diets. Nutr. Abstr. Rev. (Series B) 64:785-806.

Mutsvanga, T., I. E. Edwards, J. H. Topps and G. F. M. Paterson. 1992. The effect of dietary inclusion of yeast culture (Yeasacc) on patterns of rumen fermentation, food intakeand growth i ntervensively fed bulls. Anim. Prod. 55:35-40.

Mwenya, B., B. Santoso, C. Sar, Y. Gamo, T. Kobayashi, I. Arai and J. Takahashi. 2004. Effects of including $\beta$ 1-4 galactooligosaccharides, lactic acid bacteria or yeast culture on methanogenesis, energy and nitrogen metabolism in sheep. Anim. Feed Sci. Technol. 115: 313-326.

Newbold, C. J., B. Lassalas and J. P. Jouany. 1995. The important of methanogens associated with ciliate protozoa in ruminal methane production in vitro. Lett. Apll. Microbiol. 21:230234.

Ogimoto, K., Imai, S., 1981. Atlas of rumen microbiology. Japan Scientific Societies Press.

Patra, A.K., D.N. Kamra and N. Agarwal. 2006. Effect of plant extracts on in vitro methanogenesis, enzyme activities and fermentation of feed in rumen liquor of buffalo.
Anim. Feed Sci. Technol. 128:276-291.

Pelchen, A. and K. J. Peters. 1998. Methane emissions from sheep. Small Rum. Res. 27:137-150.

Roth, S., H. Steingass, and W. Drochner. 2001. Reducing the methane emission and optimization of $\mathrm{N}$-supply in ruminants by treating feeds with tannins. http://www.unihohenheim.de/wwwgkoll/teilpr/ suse/susee.html, accessed in May 12, 2006.

Rowe, J. B., A. Davies and A. W. J. Broome, 1985. Quantitative effects of defaunation on rumen fermentation and digestion in sheep. Br. J. Nutr. 54:105-119.

Santoso, B. 2005. Rumen fementation characteristics and methanogenesis in sheep fed silagebased diet supplemented with Yucca schidigera or Yucca schidigera combined with nisin. Buletin Peternakan 28(1):13-18.

Santoso, B., B., Mwenya, C. Sar, Y. Gamo, T. Kobayashi, R. Morikawa, K. Kimura, $\mathrm{H}$. Mizukoshi and J. Takahashi. 2004. Effects of supplementing galacto-oligosaccharides, Yucca schidigera and nisin on rumen methanogenesis, nitrogen and energy metabolism in sheep. Livest. Prod. Sci. 91: 209-217.

Santoso, B., S. Kume, K. Nonaka, K. Kimura, H. Mizukoshi, Y. Gamo and J. Takahashi. 2003. Methane emission, nutrient digestibility, energy metabolism and blood metabolites in dairy cows fed silages with and without galacto oligosaccharides supplementation. Asian- 
Aust. J. Anim. Sci. 16 (4):534540.

Shibata, M., F. Terada, K. Iwasaki, M. Krihara and T. Nishida. 1992a. Methane production in heifers, sheep and goats consuming diets of various hay-concentrate ratios. Anim. Sci. and Technol.63 (12): 1221 - 1227.

Shibata, M., F. Terada, M. Kurihara, T. Nishida and K. Iwasaki. 1992b. Estimation of methane production in ruminants. Anim. Sci. and Technol.64 (8): $790-$ 796.

Śliwiński, B. J., C. R., Soliva, A. Machmüller and M. Kreuzer. 2002. Efficacy of plant extracts rich in secondary constituents to modify rumen fermentation. Anim. Feed sci. and Technol. 101: 101-114.

Śliwiński, B. J., M. Kreuzer, H. R. Wettstein and A. Machmüller. 2002. Rumen fermentation and nitrogen balance of lambs fed diets containing plant extracts rich in tannins and saponins, and associated emissions of nitrogen and methane. Arch. Anim. Nutr. 56:379-392.

Stewart, C. S. and M. P. Bryant. 1988. The rumen bacteria. In: P. N. Hobson (ed.) The Rumen Microbiology Ecosystem. Elsevier Applied Science. London. pp. 21-75.

Stumm, C. K., H. J. Gijzen, and G. D. Vogels. 1982. Association of methanogenic bacteria with ovine rumen ciliates. Br. J. Nutr. 47:95-99.

Takahashi, J. 2001. Nutritional manipulation of methanogenesis in ruminants. Asian-Australas. J. Anim. Sci. 14:131-135.

Takahashi, J. and B. A. Young. 1997. Prophylactic effect of Lcysteine on nitrate-induced alterations in respiratory exchange and metabolic rate in sheep. Anim. Feed Sci. Technol., 35:105-113.

Takahashi, J., Y. Miyagawa, Y. Kojima and K. Umetsu. 2000. Effects of Yucca schidigera extract, probiotics, monensin and L-cysteine on rumen methanogenesis. AsianAustralas. J. Anim. Sci. 13:499. 501.

Tokura, M., K. Ushida, K. Miyazaki, and Y. Kojima. 1997. Methanogens associated with rumen ciliates. FEMS Microbiol. Ecol. 22:137-143.

Van Nevel, C. J. and D. 1. Demeyer. 1996. Control of rumen methanogenesis. Environ. Monit. Assest. 42:73-97.

Wedegaertner, T. C. and D. E. Johnson. 1983. Monensin effect on digestibility, methanogenesis and heat increament of a cracked corn-silage diet fed to steers. J. Anim. Sci. 57: 1681777.

Williams, A. G. and G. S. Coleman. 1991. The Rumen Protozoa. Springer-Verlag New York Inc., New-York, p. 441.

Wolin, M. J. 1979. The rumen fermentation : a model for microbial interactions in anaerobic ecosystems. Adv. Microbiol. Ecol. 3:49-77. 
Alamat Korespondensi: Dr. Ir. Budi Santoso

Jurusan Nutrisi dan Makanan Ternak

Fakultas Peternakan Perikanan dan Ilmu Kelautan, Universitas Negeri Papua.

Artikel diterima 28 Juli 2006, disetujui 25 September 2006 